ENCYCLOPÉDIE Encyclopédie berbère

BERBERE

28-29 | 2008

28-29 | Kirtēsii - Lutte

\title{
Libyes Aegyptii
}

\section{J. Desanges}

\section{OpenEdition}

Journals

Édition électronique

URL : http://journals.openedition.org/encyclopedieberbere/341

DOI : 10.4000/encyclopedieberbere.341

ISSN : 2262-7197

\section{Éditeur}

Peeters Publishers

\section{Édition imprimée}

Date de publication : 1 janvier 2008

Pagination : 4393-4394

ISBN : 2-7449-0707-4

ISSN : 1015-7344

\section{Référence électronique}

J. Desanges, "Libyes Aegyptii », Encyclopédie berbère [En ligne], 28-29 | 2008, document L21, mis en ligne le 01 juin 2013, consulté le 25 septembre 2020. URL : http://journals.openedition.org/ encyclopedieberbere/341; DOI : https://doi.org/10.4000/encyclopedieberbere.341

Ce document a été généré automatiquement le 25 septembre 2020

(c) Tous droits réservés 


\section{Libyes Aegyptii}

\section{J. Desanges}

1 Méla (I, 23) situe les Libyes Aegyptii à distance de la mer Libyque (Méditerranée) et à l'est, semble-t-il des Leuco[e]aethiopes* et des Gétules*. Pline l'Ancien (V, 43) les place, lui aussi, aux côtés des Leucoe Aethiopes, mais au-delà d'une zone intermédiaire de déserts. Nous savons cependant par Ptolémée (G., IV, 5, 12, Müller: 694) que les Libuaeguptii sont implantés dans le nome Maréote à l'intérieur des terres et non loin des Oasitae*, ou habitants des oasis du désert libyque. Les Libyes Aegyptii étaient donc des Libyens égyptianisés vivant dans ce désert. Ils font en quelque sorte pendant aux Arabaeguptii Ichtyophages des rivages égyptiens de la mer Rouge et des monts qui les surplombent (Ptol., ibid.).

INDEX

Mots-clés : Ethnonymie, Libye, Population/peuplement, Tribu(s) 